\title{
Seroprevalence of anti-Toxoplasma gondii antibodies in dogs from rural area of Nossa Senhora da Glória, Sergipe, Brazil*
}

\section{Soroprevalência de anticorpos anti-Toxoplasma gondii em cães de área rural de Nossa Senhora da Glória, Sergipe, Brasil}

\author{
Renata Rocha da Silva, ${ }^{* *}$ Bárbara Regina Marques, ${ }^{* * *}$ Anita de Souza Silva, ${ }^{* * *}$ \\ Victória Rafaela Nunes dos Santos, ${ }^{* * * *}$ Rivia Karoline Nascimento, ${ }^{* * * *}$ Priscila Lima dos Santos, ${ }^{* * * * * *}$ \\ Geyanna Dolores Lopes Nunes, ${ }^{* * *}$ Ana Claudia Campos, ${ }^{* * *}$ Roseane Nunes de Santana Campos ${ }^{* * * *}$
}

\begin{abstract}
Toxoplasma gondii is a protozoan parasite with worldwide distribution. Dogs are considered sentinel animals, useful for the detection of environmental infections and outbreaks of disease through serological surveys. Considering this, we aimed to assess the seroprevalence of toxoplasmosis in dogs from rural areas of the hinterland of the state of Sergipe, Northeastern Brazil. A total of 77 blood samples were collected from dogs and analyzed by the Indirect Hemagglutination test for the detection of anti-T. gondii antibodies Samples were considered positive when titers greater than or equal to 1:16 were observed. In addition, an epidemiological questionnaire designed to identify characteristics of the animal was performed to owners regarding sex, breed, age, sterilization, access to areas outside the house, environmental hygiene, contact with other animals and dog food. A total of $49.3 \%$ of dogs ( $n$ $=38$ ) were positive for anti-T. gondii antibodies, most with high titers (44.7\%). A higher relative frequency of seropositivity was observed in male dogs, not sterilized, mixed breed, which were fed exclusively on homemade food and had access to the street and contact with other animals. Taken together, our data reinforce the importance of developing health education actions within the scope of public health aimed at preventing this zoonosis.
\end{abstract}

Keywords: public health, seroprevalence, Toxoplasma gondii, zoonosis.

\section{Resumo}

Toxoplasma gondii é um protozoário com distribuição mundial. Os cães são considerados animais sentinela, úteis para a detecção de infecções ambientais e surtos da doença por meio de levantamentos sorológicos. Portanto, o presente estudo teve como objetivo determinar a soroprevalência da toxoplasmose em cães da zona rural da região rural do Alto Sertão Sergipano, Brasil. Um total de 77 amostras de sangue de cães foram coletadas no município de Nossa Senhora da Glória, Sergipe e submetidas ao teste de Hemaglutinação Indireta para detecção de anticorpos anti-T. gondii, considerando títulos maiores ou iguais a 1:16 como positivos. Além disso, foi aplicado um questionário epidemiológico aos proprietários solicitando informações sobre sexo, raça, idade, esterilização, acesso às ruas, limpeza do ambiente, contato com outros animais e ração, além de dados do proprietário, como renda familiar e nível de educação. $49,3 \%$ dos cães (38/77) apresentaram anticorpos anti-T. gondii, a maioria com títulos elevados $(44,7 \%)$. Foi observado maior frequência relativa de soropositividade em cães macho, não esterilizados, sem raça definida, que se alimentam exclusivamente de comida caseira e tem acesso a rua e contato com outros animais. Os dados obtidos reforçam a importância do desenvolvimento de ações de educação em saúde no âmbito da saúde pública voltadas à prevenção dessa zoonose.

Palavras-chave: saúde pública, soroprevalência, Toxoplasma gondii, zoonose.

\section{Introduction}

Toxoplasmosis is an anthropozoonosis with worldwide distribution and caused by a coccid protozoan of the specie Toxoplasma gondii (FERNANDES et al., 2018). Although species of the Felidae family, such as cats, are considered definitive hosts, as they are the only species where $T$. gondii complete the intestinal cycle and they eliminate infectious oocysts in the feces, the protozoan also can infect other warm-blooded animals, such as humans, bovines, and dogs (LINDSAY et al., 1997; SIMÕES et al., 2015) Domestic dogs (Canis familiaris) are considered intermediate hosts and can contribute to the spread of toxoplasmosis. Importantly, they are considered sentinel animals of the disease (OLBERA et al., 2020).

The biological cycle occurs when the definitive host ingests tissues from infected animals, usually rodents, containing T. gondii tachyzoites or bradyzoites (ETTINGER and FELDMAN, 1997;

\footnotetext{
*Recebido em 13 de setembro de 2021 e aceito em 22 de novembro de 2021.

**Programa de Pós-Graduação em Ciências da Saúde, Universidade Federal de Sergipe (UFS), Aracaju -Sergipe, Brasil.

${ }^{* * *}$ Autonomus Veterinarian, Senador Rui Palmeira, Alagoas, Brasil.

${ }^{* * *}$ Núcleo de Medicina Veterinária, Universidade Federal de Sergipe (UFS), Campus do Sertão, Nossa Senhora da Glória - Sergipe, Brasil. Autor para correspondência: roseanensc@gmail.com.

*****Departamento de Medicina, Universidade Federal de Sergipe (UFS), Lagarto - Sergipe, Brasil.

******Departamento de Educação em Saúde, Universidade Federal de Sergipe (UFS), Lagarto - Sergipe, Brasil.
} 
SIMÕES et al., 2015). It can also be transmitted through ingestion of oocysts in contaminated food or water, ingestion of cysts with bradyzoites in raw or undercooked meat, or transplacental transmission of tachyzoites (BENITEZ et al., 2017).

Dogs are susceptible to infection as they are carnivorous (BENITEZ et al., 2017). Furthermore, they have a close relationship with humans, especially women and children, which may increase the risk of transmission through oocysts in their fur (DUBEY and JONES, 2008; LINDSAY et al., 1997).

Notably, infected dogs indicates that the domestic environment may be contaminated with $T$. gondii, and may be high risk areas of infection for humans. The disease greatly impacts public health because it affects at-risk groups, including immunosuppressed individuals and pregnant women. During pregnancy, T. gondii can be transmitted through the transplacental route, affecting the fetus, and causing irreversible damage (FARIA et al., 2018; FERNANDES et al., 2018). Additionally, rural areas of Brazil are important regions for cattle raising and milk production. Therefore, the presence of infected dogs indicates that there is a risk of transmission of the parasite among cattle and humans in the region. Considering this, we aimed herein to assess the seroprevalence of anti- $T$. gondii antibodies in dogs from rural areas of the hinterland of the state of Sergipe, Northeastern Brazil.

\section{Material and Methods}

The study was conducted in rural areas of the municipality of Nossa Senhora da Glória, located in the Sertão of Sergipe, Northeastern Brazil. located in the hinterland area of Sergipe, Northeastern Brazil. The municipality is located in the upper Sertão region of Sergipe, $126 \mathrm{~km}$ from the state capital, Aracaju, has an estimated population of 37,324 inhabitants, and comprises 61 villages. It is an important region for livestock, with emphasis on the activities of cattle, sheep, goats and swine, in addition to the high milk production in the state (IBGE, 2019). The climate in this region is tropical and semiarid. The average annual precipitation is $702.4 \mathrm{~mm} 3$, the average annual temperature is $24.2\left({ }^{\circ} \mathrm{C}\right)$ and the rainy season lasts from March to August.

A descriptive observational and epidemiological study was conducted using non-probabilistic convenience sampling. The number of samples collected was calculated based on an expected prevalence of $50 \%$ T. gondii infection, since there are no previous studies of this disease in dogs in the municipality of Nossa Senhora da Glória, Sergipe (Thrusfield, 2004).

Domestic dogs older than 6 months were included in the study, regardless of sex and breed. The sampling took place during the rabies vaccination campaign in the rural area of the municipality in 2018. Only animals belonging to owners who had signed an Informed Consent form, were included in the study.

First, about $3 \mathrm{ml}$ of blood was collected by external venipuncture or cephalic venipuncture, packed into previously identified anticoagulant test tubes, and shipped to the Laboratory of Immunology. The samples were subsequently centrifuged at 2,000 rpm for five minutes to obtain the serum, which was aliquoted into microtubes, and stored at $-20^{\circ} \mathrm{C}$ until serology was performed.

In addition, an epidemiological questionnaire, designed to identify characteristics of the animal, was performed with the dog owners in the studied region. The questionnaire contained dog characteristic information such as: sex, age, breed, vaccination, food, contact with other animals, type of environment, and cleanliness of the environment.

The indirect Hemagglutination test (IHT - TOXOTEST HAI, Wiener lab. - Argentina), was performed following the manufacturer's recommendations to detect anti- $T$. gondii antibodies in serum samples. The IHT is based on the property that anti-T. gondii antibodies cause agglutination in the presence of red blood cells sensitized with antigens in the cytoplasm and membrane of the parasite. Serum samples that were agglutinated at 1:16 dilutions or greater were considered positive for toxoplasmosis.

Data obtained from the epidemiological questionnaires were tabulated using Microsoft Excel 2016 (Microsoft Corporation, Washington, United States) and presented in absolute frequency ( $\mathrm{n}$ ) and relative frequency (\%) for seropositive and seronegative dogs.

The study was approved by the Ethics Committee on the Use of Animals of the Federal University of Sergipe, registered under number 44/2017.

\section{Results}

Herein, we tested 77 dog serum samples and $49.3 \%(n=38)$ were positive for anti-T. gondii antibodies (Figure 1).

Figure 1: Seroprevalence of Toxoplasma gondii in rural area of Nossa Senhora da Glória, Sergipe

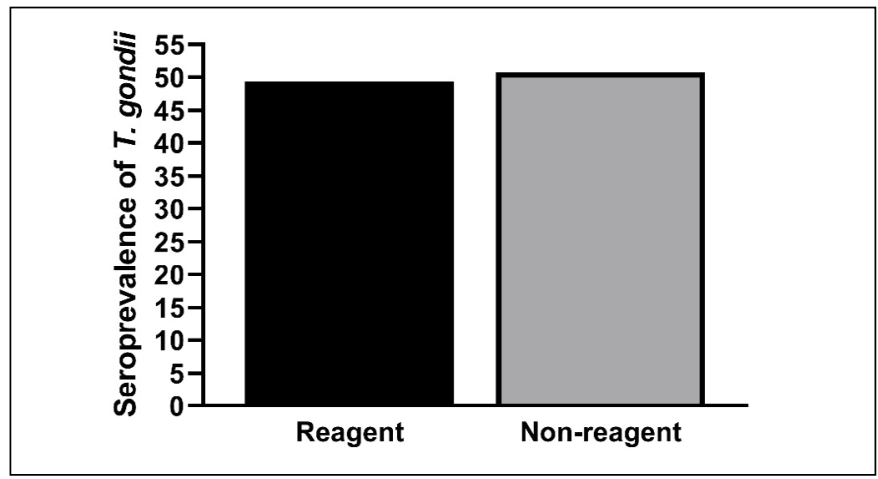

Among the 38 seropositive samples for $T$. gondii, we observed that $34.2 \%$ had a dilution of $1: 16,21.1 \%$ had $1: 32$, and $44.7 \%$ had 1:64 (Figure 2).

Figure 2: Relative frequency of antibodies titers anti- $T$. gondii in dogs from rural area of Nossa Senhora da Glória, Sergipe

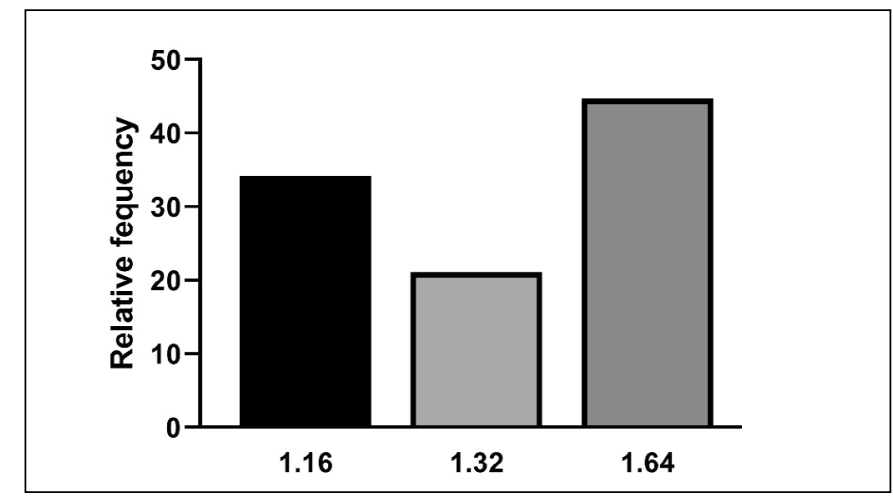


The characteristics of seropositive animals, and their management, are described in Table 1.

Table 1: Absolute and relative frequencies of variables associated with seropositive and seronegative dogs for anti-T. gondii antibodies in rural area of Nossa Senhora da Glória, SE

\begin{tabular}{|c|c|c|c|c|}
\hline \multirow{2}{*}{ Variable } & \multicolumn{2}{|c|}{ Seropositive } & \multicolumn{2}{|c|}{ Seronegative } \\
\hline & Absolute frequency (n) & Relative frequency (\%) & Absolute frequency $(n)$ & Relative frequency (\%) \\
\hline \multicolumn{5}{|l|}{ Genre } \\
\hline Male & 32 & 84.2 & 29 & 74.3 \\
\hline Female & 6 & 15.8 & 10 & 25.6 \\
\hline \multicolumn{5}{|l|}{ Sterilized } \\
\hline No & 35 & 92.1 & 38 & 97.4 \\
\hline Yes & 3 & 7.9 & 1 & 2.6 \\
\hline \multicolumn{5}{|l|}{ Breed } \\
\hline Mixed breed & 36 & 94.7 & 37 & 94.8 \\
\hline Defined Breed & 2 & 5.3 & 2 & 5.2 \\
\hline \multicolumn{5}{|l|}{ Age } \\
\hline 6 - 12 months & 4 & 10.5 & 7 & 17.9 \\
\hline $2-3$ years & 8 & 21.1 & 12 & 30.8 \\
\hline $3-4$ years & 13 & 34.2 & 17 & 43.6 \\
\hline$\geq 5$ years & 13 & 34.2 & 3 & 7.7 \\
\hline
\end{tabular}

Interestingly, most of the seropositive dogs were male (84.2\%), not sterilized (92.1\%) and were mixed breed (94.7\%). Higher relative frequency of anti- $T$. gondii antibodies $(68.4 \%)$ was also observed in animals in the age group $\geq 3$ years and in

dogs which had access to areas outside the house (84.2\%). None of the seropositive dogs had dog food as exclusive food, $81.5 \%$ of them were exclusively fed with homemade food (Table 2).

Table 2: Absolute and relative frequencies of variables associated with the environmental characteristics of seropositive and seronegative dogs for anti-T. gondii antibodies in rural area of Nossa Senhora da Glória, SE

\begin{tabular}{|c|c|c|c|c|}
\hline \multirow{2}{*}{ Variable } & \multicolumn{2}{|c|}{ Seropositive } & \multicolumn{2}{|c|}{ Seronegative } \\
\hline & Absolute frequency $(n)$ & Relative frequency (\%) & Absolute frequency (n) & Relative frequency (\%) \\
\hline \multicolumn{5}{|l|}{ Breeding type } \\
\hline $\begin{array}{l}\text { With access to the external } \\
\text { environment of the house }\end{array}$ & 32 & 84.2 & 23 & 59.0 \\
\hline Household & 6 & 15.8 & 16 & 41.0 \\
\hline \multicolumn{5}{|l|}{ Environmental hygiene } \\
\hline Not clean & 27 & 71.1 & 30 & 76.9 \\
\hline Clean & 11 & 28.9 & 9 & 23.0 \\
\hline \multicolumn{5}{|l|}{ Breeding environment } \\
\hline Cement and soil & 17 & 44.7 & 9 & 23.0 \\
\hline Soil & 21 & 55.3 & 30 & 76.9 \\
\hline \multicolumn{5}{|l|}{$\begin{array}{l}\text { Contact with other } \\
\text { animals }\end{array}$} \\
\hline Yes & 36 & 94.7 & 37 & 94.9 \\
\hline No & 2 & 5.3 & 2 & 5.1 \\
\hline \multicolumn{5}{|l|}{ Food } \\
\hline Homemade food & 31 & 81.5 & 29 & 74.4 \\
\hline Dog food & - & - & 2 & 5.1 \\
\hline Both & 7 & 18.5 & 8 & 20.5 \\
\hline
\end{tabular}


Moreover, in relation to the environmental characteristics (Table 2 ), higher relative frequency was observed in dogs which had contact with other animals, such as cows, cats and horses $(94.7 \%)$ and was raised in an unclean environment $(71.1 \%)$.

\section{Discussion}

This is the first epidemiological survey to assess the seroprevalence of anti-T. gondii antibodies in dogs from rural areas of the hinterland of the state of Sergipe, Northeastern Brazil. Herein, we conducted an observational study to describe the prevalence and factors associated with $T$. gondii infection among dogs. Notably, active search studies in endemic areas are required to understand the epidemiological situation of the disease and, thus, contributing to the planning of health services and programs (THRUSFIELD, 2004). T. gondii infections in dogs are usually asymptomatic, with most infections remaining undiagnosed (CUNHA et al., 2016). However, they are considered sentinel animals, useful for the detection of environmental infections and outbreaks; therefore, serological diagnosis in these animals is needed for monitoring toxoplasmosis (CUNHA et al., 2016; OLBERA et al., 2020).

Seroprevalence for T. gondii in dogs varies among the different regions of Brazil: $38 \%$ in municipalities in the state of Pará; $22.1 \%$ in the State of Paraíba; and $6.5 \%$ in the state of São Paulo (FERNANDES et al., 2018; OLBERA et al., 2020; PAZ et al., 2019). In this study, we demonstrated that there was a high frequency of dogs that were seropositive for anti- $T$ gondii antibodies (49.3\%). Similarly, Ornellas and collegaues (2020) reported occurrence of $50 \%$ of positive dogs from rural areas of Rio de Janeiro, and corroborates our results.

Considering the age of the animals, we observed that those aged $\geq 3$ years old are more likely to be seropositive for $T$. gondii. Similar data was also observed in studies conducted by Dantas et al. (2014) and Fernandes et al. (2018). Postnatal infection is one of the main forms of transmission of toxoplasmosis, since there is a greater risk of encountering possible sources of infection and the most varied routes of transmission (DANTAS et al., 2014; FERNANDES et al., 2018). Additionally, dogs with free access to areas outside the house was a factor associated with the seropositivity. These animals have an increased chance of becoming infected through close contact with the ground and their carnivorous behavior (BENITEZ et al., 2017; Sevá et al., 2020).

Importantly, the samples assessed herein were from rural areas. Domestic dogs have close contact with others farm animals (as cattle and rats), which are also intermediate hosts for T. gondii in rural areas (CUNHA et al., 2016). Mendonça and collegeaus (2013) observed a high seroprevalence of anti-T. gondii (28.2\%) among sheep from the state of Sergipe. Considering this, prevention guidelines must emphasize the importance of washing hands when handling raw meat and avoiding the consumption of

\section{References}

BENITEZ, A.N.; GONÇALVES, D.D.; NINO, B. S.L.; CALDART, E.T.; FREIRE, R.L.; NAVARRO, I.T. Seroepidemiology of

Toxoplasmosis in Humans and Dogs From a Small Municipality in

Parana, Brazil. Brazilian Animal Science, v. 18, p. 1-9, 2017. undercooked meat, untreated water, and unpasteurized milk from endemic areas (INAGAKI et al., 2014; SARTORI et al., 2011).

Toxoplasmosis is an anthropozoonosis that requires attention in pregnant women due to the risk of congenital infections resulting from acute maternal infection and consequent transmission of $T$. gondii through the transplacental route (INAGAKI et al., 2014; SARTORI et al., 2011). A prior study conducted in Nossa Senhora da Glória (this study area), reported a seroprevalence of anti-toxoplasma antibodies of $69.3 \%$ among pregnant women. Likewise, another study carried out in the capital of Sergipe, Aracaju city, identified a seroprevalence of $68.5 \%$ of anti- $T$. gondii among pregnant women (INAGAKI et al., 2014, 2009). Similarly, Inagaki and collegeaus (2014) and Olbera and collegeaus (2020) observed a higher prevalence of toxoplasmosis in pregnant women and domestic dogs, respectively. Positivity was higher in low-income areas, population living with lack of home and sanitary infrastructure, areas with the presence of stray animals, environmental pollution, and absence of impermeable soil, all conditions that can increase exposure to $T$. gondii and various environmental pathogens.

Taken together, these data corroborate that toxoplasmosis is still a serious public health concern in Sergipe. We conducted an observational, descriptive study that has some limitations. Sample collection was carried out in rural areas during the city's anti-rabies vaccination campaign and only included animals whose guardians agreed to answer the questionnaire and to collect blood from the dogs. Moreover, we do not include non-domiciled animals and this may underestimate the real prevalence of toxoplasmosis in the region. Finally, the limited sample size may have affected the data analyses. Despite this, our findings demonstrate a high rate of seropositivity for toxoplasmosis among domestic dogs in the interior of Sergipe and that the disease situation may be even more serious in this important livestock region.

\section{Conclusions}

Altogether, our data show a high percentage of positive dogs for anti-T. gondii in rural areas of Sergipe state, Northeast Brazil. Some factors such as age above 3 years and access to the external environment of the home were associated with the seropositivity for toxoplasmosis. Herewith, our findings suggest that the situation of toxoplasmosis in Sergipe is still serious. Furthermore, the study area is an important region for cattle raising and marketing of meat, milk, and its derivatives. The high positivity of the disease among dogs, which are sentinel animals, indicates a high risk of local transmission of the parasite. Therefore, it is important that public health authorities invest in broader investigations into toxoplasmosis in Sergipe and to develop actions aimed at preventing and controlling this important zoonosis that represents a risk to public health.

BURSAC, Z.; GAUSS, C.H.; WILLIAMS, D.K.; HOSMER, D.W. Purposeful selection of variables in logistic regression. Source Code for Biology and Medicine, v. 3, n. 17, 2008. 
CUNHA, N.C.; CORDEIRO, M.D.; ANTUNES CARDOSO, S.B.; MATOS, P.C.M.; ALMOSNY, N.R.P.; FONSECA, A.H. Seroepidemiology of Toxoplasma gondii in dogs in the state of Rio de Janeiro. Brazilian Journal Veterinary Medicine, v. 38, s. 3, p.109-112, 2016.

DANTAS, S.B.A.; FERNANDES, A.R.F.; SOUZA NETO, O.L.; MOTA, R.A.; ALVES, C.J.; AZEVEDO, S.S. Risk factors for the occurrence of antibodies against Toxoplasma gondii and Neospora caninum in domiciled dogs in Northeastern Brazil. Seminar: Agricultural Sciences, v. 35, n. 2, p. 875-881, 2014.

DUBEY, J.; JONES, J. Toxoplasma gondii infection in humans and animals in the United States. International Journal for Parasitoly, v. 38, p. 1257-1278, 2008.

ETTINGER, S.J.; FELDMAN, E.C. Veterinary Internal Medicine, 4th ed. Manole, São Paulo, 1997.

FARIA, G.; LUZ, G.S.; BETIN, T.A. Incidence of toxoplasmosis in gestation - A problem of public health in the Cacoal-Ro municipality. FAEMA Scientific Journal. v.9, n. 2, p. 692-697, 2018.

FERNANDES, A.R.F.; COSTA, D.F.; ANDRADE, M.R.; BEZERRA, C.S.; MOTA, R.A.; ALVES, C.J.; LANGONI, H.; AZEVEDO, S.S. Seropositivity and risk factors for leptospirosis, toxoplasmosis and neosporosis in the canine population of Paraiba state, northeastern Brazil. Brazilian Journal of Veterinary Research, $v$. 38, n. 5, p. 957-966, 2018

IBGE. Nossa Senhora da Glória, Sergipe - Brazil. Brazilian Institute of Geography and Statistics. [online]. 2019 [cited 2020 Feb 25]. Available from: https://cidades.ibge.gov.br/brasil/se/ nossa-senhora-da-gloria.

INAGAKI, A.D.M., CARDOSO, N.P., LOPES, R.J.P.L., ALVES, J.A.B., MESQUITA, J.R.F., ARAÚJO, K.C.G.M., KATAGIRI, S. Spatial analysis of the prevalence of toxoplasmosis in pregnant women from Aracaju, Sergipe, Brazil. Brazilian Journal of Gynecology and Obstetrics, v. 36, n. 12, p. 535-540, 2014.

INAGAKI, A.D.M.; OLIVEIRA, L.A.R.; OLIVEIRA, M.F.B.; SANTOS, R.C.S.; ARAÚJO, R.M.; ALVES, J.A.B.; PINHEIRO, K.S.; GURGEL, R.Q.; MUSSI-PINHATA, M.M. Seroprevalence of antibodies to toxoplasmosis, rubella, cytomegalovirus, syphilis, and HIV in pregnant women from Sergipe. Journal of the Brazilian Society of Tropical Medicine, v. 42, n. 5, p. 532-536, 2009.

LINDSAY, D.S.; DUBEY, J.P.; BUTLER, J.M.; BLAGBURN, B.L. Mechanical transmission of Toxoplasma gondii oocysts by dogs. Veterinary Parasitoly, v. 73, p. 27-33, 1997.
MENDONÇA, C.E.D.A.; BARROS, S.L.B.; GUIMARÃES, V.A.A.; FERRAUDO, A.S.; MUNHOZ, A.D. Prevalence and risk factors associated to ovine toxoplasmosis in northeastern Brazilian. Brazilian Journal of Veterinary Parasitoly, v. 22, n. 2, p. 230-234, 2013.

OLBERA, A.V.G.; FORNAZARI, F.; BABBONI, S.D.; ROSSI, R.S.; SEVÁ, A.P.; LATOSINSKI, G.S.; SILVA, M.A.R.X.; MODOLO, J.R.; LANGONI, H. Cumulative incidence and spatial distribution of dogs exposed to Toxoplasma gondii. Brazilian Journal of Veterinary Parasitoly, v. 29, n. 2, p. 1-8, 2020.

ORNELLAS, R.O.; LIMA BARBOSA FILHO, C.J.; ALVES ALBUQUERQUE, D.D.; PASSOS CORDEIROS, J.L.; FERREIRA GREMIÃO, I.D.; PEREIRA, S.A.; LANGONI, H.; ROSA SANTOS, J.; BELO, V.S.; BORGES FIGUEIREDO, F. Seroprevalence of leishmaniasis, toxoplasmosis, and leptospirosis in the domestic fauna of an anthropized environment of the Atlantic Forest in the city of Rio de Janeiro. Archives Veterinary Science, v. 25, n. 2, p. 13-20, 2020.

PAZ, G.S.; COLHADO, B.S.; ANTON, M.M.; ROCHA, K.S.; SILVA, D.B.; MORAES, C.C.G.; LUCHEIS, S.B.; LANGONI, H. Infection with Toxoplasma gondii, Neospora caninum, Leishmania major, and Trypanosoma cruzi in dogs from the state of Pará. Brazilian Animal Science, v. 20, p. 1-10.

SARTORI, A.L.; MINAMISAVA, R.; AVELINO, M.M.; MARTINS, C.A. Prenatal screening for toxoplasmosis and factors associated with seropositivity of pregnant women in Goiânia, Goiás. Brazilian Journal of Gynecology and Obstetrics, v. 33, n. 2, p. 93-98, 2011.

SEVÁ, A.P.; CHIEBAO, D.P.; BRANDÃO, A.P.D.; GODOY, S.N.; JIMENEZ-VILLEGAS, T.; PENA, H.F.J.; FERREIRA, F. Seroprevalence and incidence of toxoplasma gondii and neospora caninum infection in naturally exposed domestic dogs from a rural area of São Paulo State, Brazil. Brazilian Journal Veterinary Parasitoly, v. 29, n. 3, p. 1-13, 2020.

SIMÕES, L.; FAVARON, P.O.; ANUNCIAÇÃO, A.R.A. Toxoplasma Gondii and pregnancy: characteristics of toxoplasmosis, clinical signs, diagnosis, and the importance of the disease in public health - Review. Journal of Veterinary Medical Science, v. 25, p. 1-17, 2015.

THRUSFIELD, M.V. Veterinary Epidemiology, 2nd ed. Roca, São Paulo, 2004. 